\title{
An investigation of high intensity ultrasonication and chemical immersion treatments on Campylobacter jejuni and spoilage bacteria in chicken
}

\author{
Ahmed Kassem \\ University College Dublin \\ Joseph Meade \\ University College Dublin \\ Kevina McGill \\ University College Dublin
}

See next page for additional authors

Follow this and additional works at: https://arrow.tudublin.ie/schfsehart

Part of the Food Science Commons, and the Medicine and Health Sciences Commons

\section{Recommended Citation}

Ahmed Kassem, Joseph Meade, Kevina McGill, Ciara Walsh, James Gibbons, James Lyng, Paul Whyte, An investigation of high intensity ultrasonication and chemical immersion treatments on Campylobacter jejuni and spoilage bacteria in chicken, Innovative Food Science \& Emerging Technologies, Volume 45, 2018, Pages 298-305, ISSN 1466-8564, DOI: 10.1016/j.ifset.2017.10.015.

This Article is brought to you for free and open access by the School of Food Science and Environmental Health at ARROW@TU Dublin. It has been accepted for inclusion in Articles by an authorized administrator of ARROW@TU Dublin. For more information, please contact arrow.admin@tudublin.ie, aisling.coyne@tudublin.ie, gerard.connolly@tudublin.ie.

Funder: Iraqi Ministry of Higher Education; University of Kufa 


\section{Authors}

Ahmed Kassem, Joseph Meade, Kevina McGill, Ciara Walsh, James Gibbons, James Lyng, and Paul Whyte 


\title{
An investigation of high intensity ultrasonication and chemical immersion treatments on Campylobacter jejuni and spoilage bacteria in chicken
}

\author{
Ahmed Kassem $^{\mathrm{a}, \mathrm{d}, *}$, Joseph Meade ${ }^{\mathrm{a}}$, Kevina McGill ${ }^{\mathrm{a}}$, Ciara Walsh ${ }^{\mathrm{c}}$, James Gibbons ${ }^{\mathrm{a}}$, James Lyng ${ }^{\mathrm{b}}$, \\ Paul Whyte ${ }^{\mathrm{a}}$
}

a School of Veterinary Medicine, University College Dublin, Belfield, Dublin 4, Ireland

${ }^{\mathrm{b}}$ School of Agriculture and Food Science, University College Dublin, Belfield, Dublin 4, Ireland

${ }^{c}$ School of Food Science \& Env. Health, Dublin Institute of Technology, Ireland

${ }^{\mathrm{d}}$ Faculty of Veterinary Medicine, University of Kufa, Iraq

\section{A R T I C L E I N F O}

Chemical compounds studied in this article: Lactic acid (PubChem CID:612)

Sodium decanoate (PubChem CID:4,457,968)

Trisodium phosphate (PubChem CID:24,243)

Keywords:

Ultrasonication

Thermosonication

Chemical immersions

Campylobacter

Chicken decontamination

\begin{abstract}
A B S T R A C T
High intensity ultrasonication (US) alone or in combination with chemical immersion treatments of lactic acid (3\% LA), sodium decanoate ( $3 \% \mathrm{SD}$ ) and trisodium phosphate (10\% TSP) were investigated to reduce populations of Campylobacter jejuni and spoilage organisms in raw chicken. Different experimental conditions were used including a range of temperatures $\left(4^{\circ} \mathrm{C}, 25^{\circ} \mathrm{C}\right.$ and $\left.54^{\circ} \mathrm{C}\right)$ and exposure times $(1,2$ and $3 \mathrm{~min})$. All combination treatments significantly reduced $C$. jejuni compared to their individual treatments while only the combination US + SD significantly reduced Total Viable Count (TVC). Multiple linear regression predicted bacterial reductions resulting from changing treatment, temperature and time or each group of microorganisms. Increasing temperature from $4{ }^{\circ} \mathrm{C}$ to $54^{\circ} \mathrm{C}$ would enhance $C$. jejuni, TVC and Total Enterobacteriaceae Count (TEC) reductions by $0.73,1.02$ and $1.37 \log _{10} \mathrm{cfu} / \mathrm{g}$ respectively. Increasing time from 1 to 3 min enhanced bacterial dependent of $C$. jejuni and TEC by 0.49 and $0.31 \log _{10} \mathrm{cfu} / \mathrm{g}$ respectively.

Industrial relevance.

This study demonstrates the potential application of high intensity ultrasomication alone or in combination with chemical treatments to reduce bacterial contamination of chicken carcasses. Different tempretures and times were investigated to optimize the most effective treatments conditions in chicken abattoirs.
\end{abstract}

\section{Introduction}

Campylobacter jejuni is the most frequently reported bacterial gastrointestinal foodborne pathogen in the EU since 2005. The number of confirmed case of human campylobacteriosis in Europe has been estimated as 229,213 with an infection rate of 65.5 per 100,000 for 2015 (European Food Safety Authority (EFSA), 2015). The Health Protection Surveillance Center (HPSC) in Ireland reports that the numbers of notified campylobacteriosis cases has increased over the last 5 years in Ireland, with a total of 2451 cases were recorded (equivalent to a crude incidence rate of 53.4 per 100,000) in 2015 (HPSC, 2016). In addition, it has been indicated that the economic costs associated with campylobacteriosis to the public health systems and to lost productivity is $€ 2.4$ billion annually (European Food Safety Authority, 2014). Poultry meat is considered one of the main sources of $C$. jejuni worldwide and the prevalence of this pathogen is frequently high in raw poultry meat within the EU (EFSA, 2013; Food Safety Authority of Ireland, 2011; Whyte et al., 2004). Quantitative microbiological risk assessments have indicated that even partial reduction in $C$. jejuni numbers on chicken carcasses ( $>1 \log _{10}$ per carcass) can significantly reduce the infection rate in humans (Lindqvist \& Lindblad, 2008). Several quantitative risk assessments of Campylobacter in chicken indicated that the most effective intervention measures were those aimed at reducing the Campylobacter concentrations, rather than reducing the prevalence of contaminated carcasses (Nauta et al., 2009). Control of Campylobacter requires enhanced practices at all stages of the broiler production chain to limit exposure risks to consumers. Improved biosecurity may be the most efficient strategy to minimize the risk of colonization of this microorganism in the intestinal tract of birds (Smith et al., 2016). However, such preventative measures at farm level may increase costs, need to be consistently applied at all stages of production and have not always resulted in reduced Campylobacter levels in flocks (Food Safety Authority of Ireland, 2002; Patriarchi et al., 2009; Rosenquist et al., 2009). Effective interventions during slaughtering and processing stage are desirable, economically feasible and can be applied to high risk batches of birds in order to decrease contamination and to reduce the

\footnotetext{
* Corresponding author at: School of Veterinary Medicine, University College Dublin, Belfield, Dublin 4, Ireland.

E-mail address: ahmed.hushimat@ucdconnect.ie (A. Kassem).
} 
risk of human exposure to contaminated chicken meat (Bolder, 1997; Del Río, Panizo-Morán, Prieto, Alonso-Calleja, \& Capita, 2007; Loretz, Stephan, \& Zweifel, 2010; Mani-López, García, \& López-Malo, 2012).

Organic acids and trisodium phosphate (8-12\%) are both categorized as 'generally recognized as safe' (GRAS) for use in food production (Demirci \& Ngadi, 2012; USDA-FSIS, 1996). These chemicals have been used in the USA and Canada for many years as sprays or in immersion systems to reduce bacterial contamination and improve shelf life (Capita, Alonso-Calleja, Garcia-Fernandez, \& Moreno, 2002; USDAFSIS, 1996). In contrast, the European regulations have supported the application of strict hygiene precautions along the production process rather than using chemical interventions.

However, recently the European Commission has approved the use of lactic acid for bacterial decontamination of beef carcasses (The European Commission, 2013). The mechanism of action of organic acids is thought to result in the permeation of the cell membrane, lowering of intracellular $\mathrm{pH}$, and disruption of important cellular processes; while medium chain fatty acids such as capric acid may damage the lipid bilayer causing cell contents to leak (Alexandre, Mathieu, \& Charpentier, 1996; Dibner \& Buttin, 2002). Physical methods such as ultrasonication are considered as emerging technologies with potential applications in the food industry. Ultrasonication has been assessed as a technology to aid in the tenderization of meat, speed up maturation and mass transfer, decrease cooking energy, and increase the shelf life of meat by reducing microbial populations without effecting the quality and sensory characteristics of meat (Alarcon-Rojo, Janacua, Rodriguez, Paniwnyk, \& Mason, 2015; Awad, Moharram, Shaltout, Asker, \& Youssef, 2012). Ultrasound waves produce alternating compression and decompression within liquids which leads to the formation of cavitation bubbles, which generate very high local temperatures and pressures when they grow and suddenly collapse (Cárcel, García-Pérez, Benedito, \& Mulet, 2012). The irregular collapse of a cavitation bubble leads to a liquid jet accelerating through the center of the collapsing bubble producing high energy shock waves - which can cause damage to the cell wall of bacteria (Chandrapala, Oliver, Kentish, \& Ashokkumar, 2012). Additionally, the effect of localized high temperatures can produce free radicals which may cause DNA injury, and microstreaming which results in thinning of cell membranes leading to loss of cell viability (Bermúdez-Aguirre, Mobbs, \& Barbosa-Cánovas, 2011). The cumulative effect of such localized high temperatures is an increase in the general temperature of the liquid medium (Chen et al., 2012). Susceptibility of microorganisms to ultrasound is dependent on a range of factors. In general, endospores and viruses show increased resistance, while Gram-negative bacteria are more susceptible than Gram-positive bacteria. Cell morphology can also affect susceptibility with larger cells typically being more sensitive than small cells and rod shaped bacteria more susceptible than cocci (Torley \& Bhandari, 2004). It has been previously suggested that ultrasonication technology could be used in broiler processing as the relatively small carcasses could be immersed in dedicated ultrasonication tanks (Bolder, 1997). Furthermore, the effectiveness of ultrasonication could be enhanced by it combining with heat (Chandrapala et al., 2012; Haughton et al., 2012), or with chemical treatments (Koolman, Whyte, Meade, Lyng, \& Bolton, 2014). The objective of the current study was to investigate the effectiveness of ultrasonication treatments applied alone, or in combination with chemical immersion, to reduce Campylobacter and spoilage bacteria at different times and temperatures.

\section{Materials and methods}

\subsection{Preparation of bacterial suspensions and inoculation of samples}

Suspensions of $C$. jejuni (1146 chicken isolate) were prepared by inoculating $20 \mathrm{ml}$ aliquots of Mueller-Hinton Broth (MHB) (Oxoid,UK, CM0405) containing Campylobacter growth supplement with a single colony of the isolate and incubated for $24 \mathrm{~h}$ at $42^{\circ} \mathrm{C}$ under microaerobic conditions. A total of ten of the $20 \mathrm{ml}$ aliquots were then combined to make up $200 \mathrm{ml}$ volumes, and diluted with $300 \mathrm{ml}$ of maximum recovery diluent (MRD), (OxoidCM0733) to give a $500 \mathrm{ml}$ volume containing a cell concentration of approximately $7 \log _{10} \mathrm{cfu} / \mathrm{ml}$. Chicken thigh pieces were purchased from retail outlets and dipped in the $500 \mathrm{ml}$ volumes of the $C$. jejuni suspension for $60 \mathrm{~s}$ then left for $30 \mathrm{~min}$ to allow attachment to occur. Background levels of TVC and TEC were determined in control samples and compared to those following treatment in order to calculate bacterial reductions achieved for each treatment. Levels of $C$. jejuni on chicken skin samples following inoculation were confirmed as $5.7 \log _{10} \mathrm{cfu} / \mathrm{g}$ and reductions caused by treatments were calculated based on the difference in counts between control and treated samples.

\subsection{Chemical and ultrasonication treatments}

Each experiment was repeated in triplicate on three separate occasions at three different temperatures $\left(4,25\right.$ and $\left.54{ }^{\circ} \mathrm{C}\right)$. For each of the temperatures, chicken thighs were immersed for 3 different exposure times (1, 2 or $3 \mathrm{~min}$ ) in $3 \%$ lactic acid (LA) (Sigma Aldrich, USA, W261114), sodium decanoate (SD) (Sigma-Aldrich, USA, C4151) and $10 \%$ trisodium phosphate (TSP) (Sigma-Aldrich, USA, 222,003) alone, or in combination with ultrasonication. The ultrasonication bath used in the study was a Quirumed 534 C200 (Quirumed S.L.,Valencia, Spain) with a frequency of $40 \mathrm{kHz}$, ultrasound power of $120 \mathrm{~W}$, temperature range: $20-80$ and a 51 capacity. A thermocouple (Traceable VWR, USA) was used to monitor temperatures in each experiment. A temperature of $4{ }^{\circ} \mathrm{C}$ was maintained by immersing cooler packs in the US bath. Treatment temperatures $\left(25\right.$ and $\left.54{ }^{\circ} \mathrm{C}\right)$ were controlled by an in-built heating element and thermostat within the US bath. A volume of $1.5 \mathrm{~L}$ of each solution was used in the bath for all treatments. In addition, immersion treatments in water with and without sonication were also carried out. Following treatment, samples were immersed in $1.5 \mathrm{~L}$ distilled water for $15 \mathrm{~s}$ to rinse off any residual chemical. After washing three $5 \mathrm{~g}$ pieces of skin were aseptically removed from each thigh for analysis. Untreated control samples were microbiologically analyzed directly without any chemical or washing treatment step. Washed control (WC) samples were immersed in distilled water only then rinsed in another $1.5 \mathrm{~L}$ distilled water prior to microbiological analysis.

\subsection{Microbiological analysis}

Samples were stomached (Colworth Stomacher 400, UK) for $30 \mathrm{~s}$ in $45 \mathrm{ml} \mathrm{MRD}$, and serially diluted (1:10) in MRD before being plated in duplicate onto tazobactam modified Charcoal Cefoperazone Deoxycholate Agar (TmCCDA) (Smith et al., 2015) (Oxoid, UK, CM0739) containing a selective supplement (Oxoid, UK, SR0155E) and incubated microaerobically at $42{ }^{\circ} \mathrm{C}$ for $48 \mathrm{~h}$ - in order to enumerate $C$. jejuni. Samples were also plated in duplicate for total viable counts on Plate Count Agar (PCA) (Oxoid, UK, CM0325) at $30^{\circ} \mathrm{C}$ for $48 \mathrm{~h}$ and for total Enterobacteriaceae counts (TEC) on Violet Red Bile Glucose Agar (VRBGA) (Oxoid, UK, CM1082) at $37^{\circ} \mathrm{C}$ for $24 \mathrm{~h}$.

\subsection{Statistical analysis}

Microbial counts were converted to $\log _{10} \mathrm{cfu} / \mathrm{g}$. A multiple liner regression model was then run to predict the significant effect of treatment, temperature and time on bacterial reductions between various treatment groups. To compare significant differences between treatments a 1-way ANOVA was used followed by Tukey multiple comparison tests. Significance was determined at the $P<0.05$ level. Data was analyzed using IBM SPSS software (IBM SPSS statistics 24 Software, Armonk, New York, United States, www.IBM.com). 


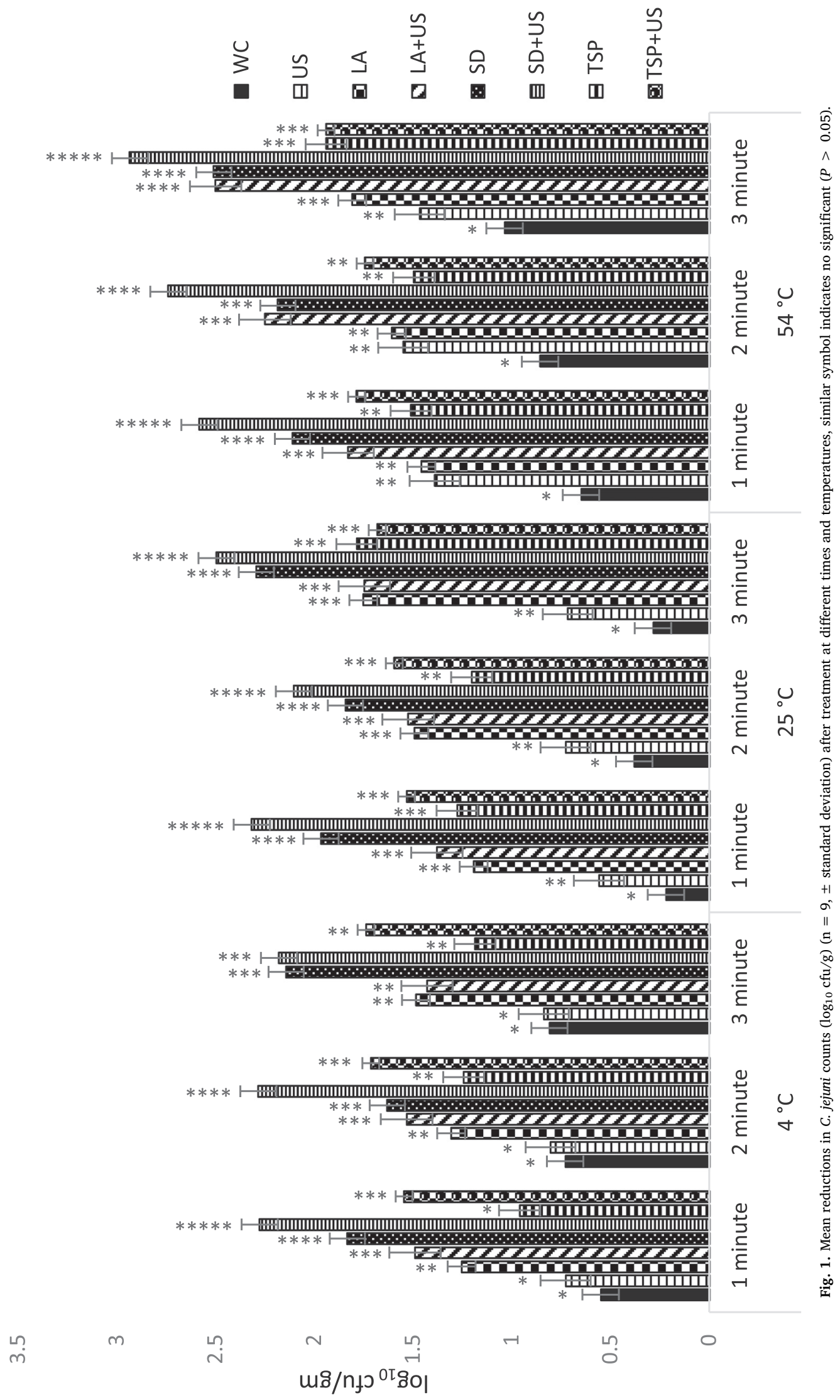




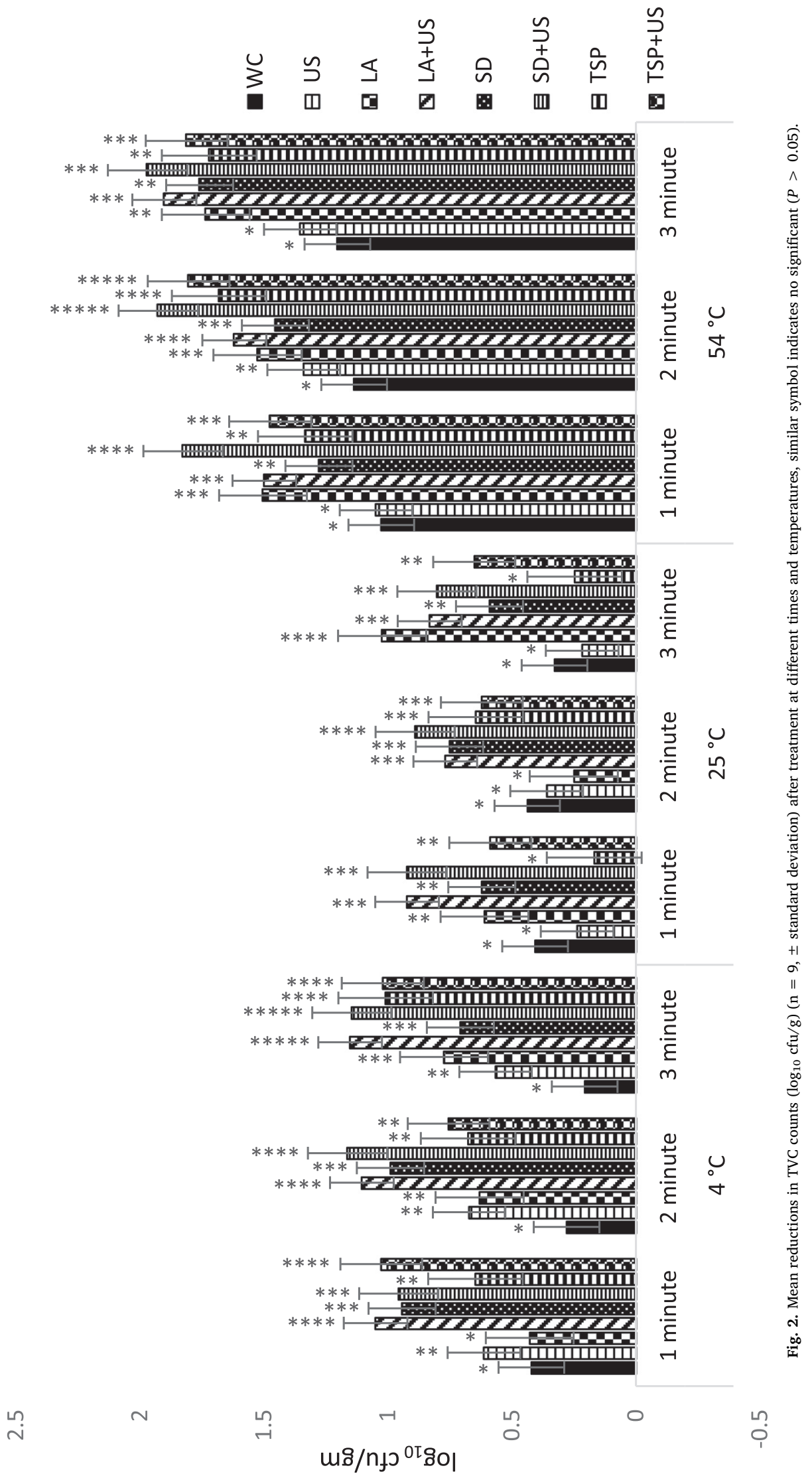




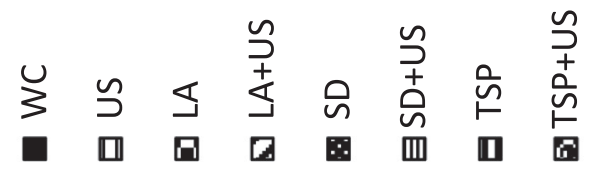
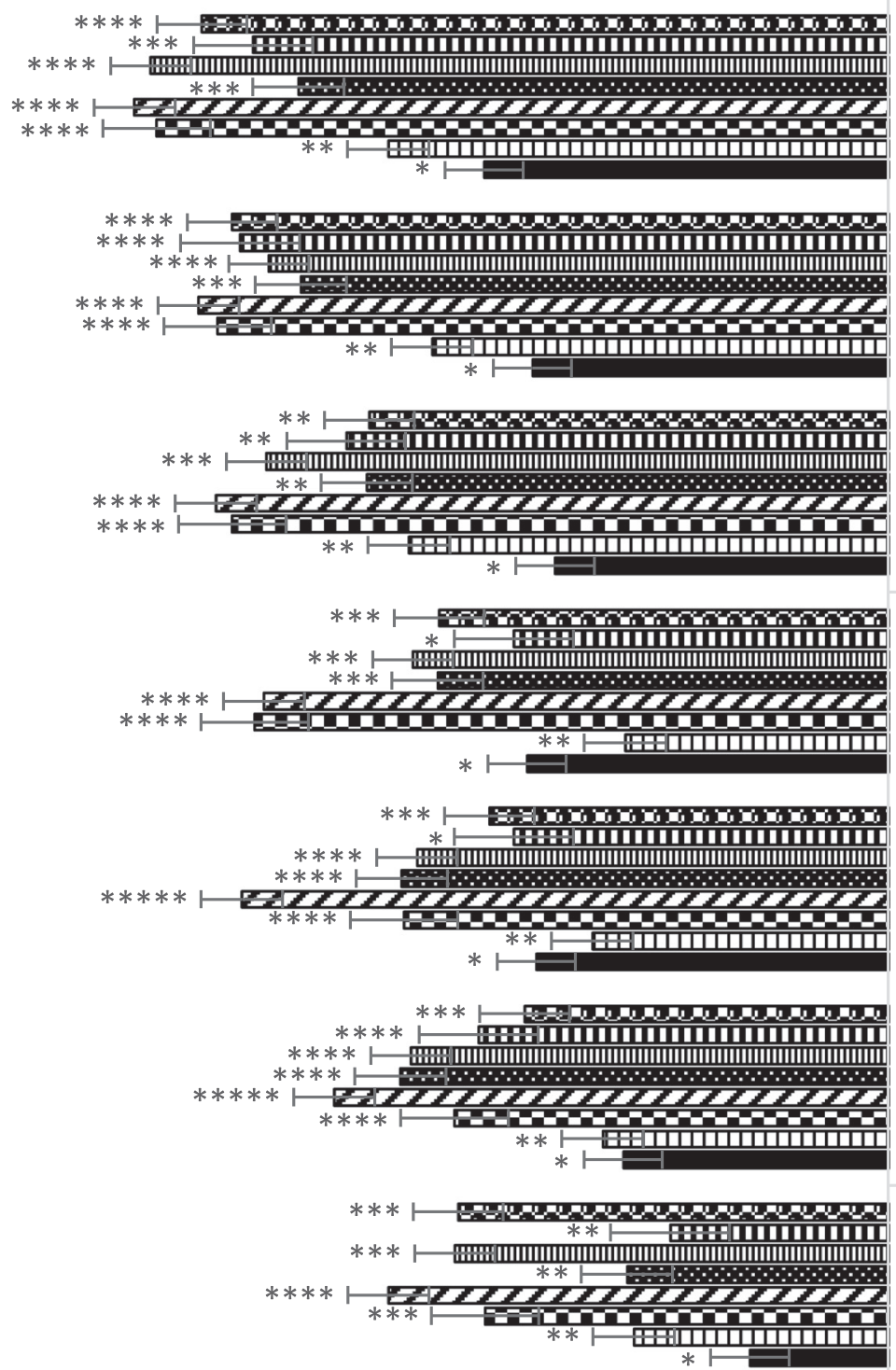

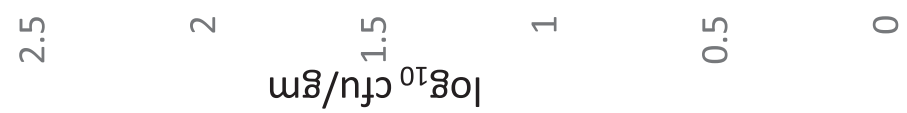


Table 1

Mean differences in C. jejuni reductions $\left(\log _{10} \mathrm{cfu} / \mathrm{g}\right)$ between wash control, individual and combination treatments.

\begin{tabular}{llll}
\hline Treatments & LA + US & SD + US & TSP + US0 \\
\hline WC & $1.13^{*}$ & $1.82^{*}$ & $1.09^{*}$ \\
US & $0.77^{*}$ & $1.46^{*}$ & $0.72^{*}$ \\
LA & $0.26^{*}$ & NA & NA \\
SD & NA & $0.38^{*}$ & NA \\
TSP & NA & NA & $0.30^{*}$ \\
\hline
\end{tabular}

$\mathrm{NA}=$ not applicable.

${ }^{*}$ Indicate the significant $(P<0.05)$ difference between treatments.

Table 2

Mean differences in TVC reductions $\left(\log _{10} \mathrm{cfu} / \mathrm{g}\right)$ between wash control, individual and combination treatments.

\begin{tabular}{llll}
\hline Treatments & LA + US & SD + US & TSP + US \\
\hline WC & $0.60^{*}$ & $0.68^{*}$ & $0.48^{*}$ \\
US & $0.49^{*}$ & $0.58^{*}$ & $0.37^{*}$ \\
LA & 0.26 & NA & NA \\
SD & NA & $0.27^{*}$ & NA \\
TSP & NA & NA & 0.18 \\
\hline
\end{tabular}

$\mathrm{NA}=$ not applicable.

${ }^{*}$ Indicate the significant $(P<0.05)$ difference between treatments.

Table 3

Mean differences in TEC reductions $\left(\log _{10} \mathrm{cfu} / \mathrm{g}\right.$ ) between wash control, individual and combination treatments.

\begin{tabular}{llll}
\hline Treatments & LA + US & SD + US & TSP + US \\
\hline WC & $0.99^{*}$ & $0.76^{*}$ & $0.60^{*}$ \\
US & $0.82^{*}$ & $0.59^{*}$ & $0.43^{*}$ \\
LA & 0.22 & NA & NA \\
SD & NA & 0.24 & NA \\
TSP & NA & NA & 0.19 \\
\hline
\end{tabular}

$\mathrm{NA}=$ not applicable

${ }^{*}$ Indicate the significant $(P<0.05)$ difference between treatments.

\section{Results}

\subsection{Summary of observed differences in microbial reductions}

The results of the current study showed a significant difference $(P<0.05)$ between the wash control samples and all other treatments to reduce $C$ jejuni with the exception of US treatments at $4{ }^{\circ} \mathrm{C}$ (Fig. 1). The greatest levels of bacterial reductions were consistently observed following SD + US treatments across all temperature time combinations. Fig. 2 shows the reduction in TVC after the same treatments; no significant differences $(P>0.05)$ were observed between wash control and US only at $25^{\circ} \mathrm{C}$ and $54^{\circ} \mathrm{C}$, while the difference was significant $(P<0.05)$ at $4{ }^{\circ} \mathrm{C}$. Fig. 3 shows a significant difference $(P<0.05)$ between wash control and US at $4{ }^{\circ} \mathrm{C}$ and $54{ }^{\circ} \mathrm{C}$ while no significant difference was observed at $25{ }^{\circ} \mathrm{C}$ for TEC $(P>0.05)$. In general, the greatest reduction in TEC were observed following treatment with LA + US.

\subsection{Comparison between individual and combination treatments}

Combination treatments of chemicals and ultrasound consistently resulted in significantly greater reductions of $C$. jejuni when compared to each individual treatment $(P<0.05)$ (Table 1$)$. In contrast, the multiple comparison of TVC reductions showed that the combination of US + SD resulted in significantly greater $(P<0.05)$ reductions than treatment with SD alone (Table 2). No significant difference $(P>0.05)$ was observed between other individual and combination
Table 4

Significant predictors of reductions in $C$. jejuni counts identified by multiple linear regression modelling.

\begin{tabular}{|c|c|c|c|c|}
\hline \multirow[t]{2}{*}{ Independent variable } & \multicolumn{2}{|c|}{ Unstandardized coefficients } & \multirow[t]{2}{*}{$\mathrm{t}$} & \multirow[t]{2}{*}{ Sig. } \\
\hline & B & Std. error & & \\
\hline Temperature & 0.243 & 0.025 & 9.684 & $<0.0001$ \\
\hline Time & 0.162 & 0.025 & 6.458 & $<0.0001$ \\
\hline Treatment & 0.162 & 0.010 & 16.574 & $<0.0001$ \\
\hline
\end{tabular}

$\mathrm{F}(3.645)=1312,402,(P<0.001), \mathrm{R} 2=0.859$.

a. Dependent variable: reduction.

b. Linear regression through the Origin.

Table 5

Significant predictors of reductions in TVC counts identified by multiple linear regression modelling.

\begin{tabular}{|c|c|c|c|c|}
\hline \multirow[t]{2}{*}{ Independent variable } & \multicolumn{2}{|c|}{ Unstandardized coefficients } & \multirow[t]{2}{*}{$\mathrm{t}$} & \multirow[t]{2}{*}{ Sig. } \\
\hline & B & Std. error & & \\
\hline Temperature & 0.341 & 0.020 & 17.385 & $<0.0001$ \\
\hline Time & 0.033 & 0.020 & 1.666 & 0.09 \\
\hline Treatment & 0.052 & 0.008 & 6.760 & $<0.0001$ \\
\hline
\end{tabular}

$\mathrm{F}(3.645)=1477,95,(P<0.001), \mathrm{R} 2=0.873$.

a. Dependent variable: reduction.

b. Linear regression through the Origin.

Table 6

Significant predictors of reductions in TEC counts identified by multiple linear regression modelling.

\begin{tabular}{lllll}
\hline \multirow{2}{*}{ Independent variable } & \multicolumn{2}{l}{ Unstandardized coefficients } & $\mathrm{t}$ & \multirow{2}{*}{ Sig. } \\
\cline { 2 - 3 } & $\mathrm{B}$ & Std. error & & \\
\hline Temperature & 0.455 & 0.008 & 21.506 & $<0.0001$ \\
Time & 0.104 & 0.001 & 4.908 & $<0.0001$ \\
Treatment & 0.057 & 0.020 & 6.944 & $<0.0001$ \\
\hline
\end{tabular}

$\mathrm{F}(3.645)=1477,95,(P<0.001), \mathrm{R} 2=0.873$.

a. Dependent variable: reduction.

b. Linear regression through the Origin.

treatments although all combination treatments produced significantly greater reductions than WC and US alone. Finally, combination treatments of ultrasound and chemicals did not result in significantly $(P>0.05)$ greater reductions in TEC compared to individual treatments (Table 3 ).

\subsection{Multiple linear regression models}

Multiple linear regression models were constructed to predict the reductions in $C$. jejuni, TVC and TEC with temperature, time and treatment as predictor variables. Temperature and treatment were significant predictors of bacterial reduction in all three models (Tables 4, 5 and 6). Time was a significant predictor of bacterial reduction in the models for $C$. jejuni and TEC. Table 4 shows unstandardized coefficient beta and $t$ values which represent changes in $C$. jejuni reductions associated with each independent variable (temperature, time and treatment). The model predicted that an increase in temperature from $4{ }^{\circ} \mathrm{C}$ to $54{ }^{\circ} \mathrm{C}$ would result in an increased reduction in $C$. jejuni counts of $(3 * 0.243)$ equal to $0.73 \log _{10} \mathrm{cfu} / \mathrm{g}$. Table 5 shows the same values for TVC reductions associated with each of the independent variables (temperature, time and treatment). An increase in temperature from $4{ }^{\circ} \mathrm{C}$ to $54{ }^{\circ} \mathrm{C}$ would result in a reduction in TVC of $1.02 \log _{10} \mathrm{cfu} / \mathrm{g}$. Table 6 shows the statistically significant $(P<0.0001)$ unstandardized coefficient beta and $t$ values associated with TEC reductions for each of 
the independent variables. The model predicted that a change in temperature from $4{ }^{\circ} \mathrm{C}$ to $54^{\circ} \mathrm{C}$ would increase the bacterial reduction by $1.37 \log _{10} \mathrm{cfu} / \mathrm{g}$ while extending treatment time from 1 to $3 \mathrm{~min}$ would result in reduction of TEC by $(3 * 0.104)$ or $0.31 \log _{10} \mathrm{cfu} / \mathrm{g}$.

\section{Discussion}

The current study investigated the effect of chemicals applied alone or in combination with ultrasonication to reduce microbial populations on raw chicken using various time and temperature combinations. Ultrasonication is a promising alternative technology to replace traditional treatments which have been used to reduce bacterial contamination, with the limited impact on food quality (Alarcon-Rojo et al., 2015). Many studies have been published to date have assessed the ability of various chemicals to reduce microbial populations on raw chicken meat (Alonso-Hernando, Alonso-Calleja, \& Capita, 2013; Capita, Alonso-calleja, Sierra, Moreno, \& Garcõâa-ferna, 2000; Chaine, Arnaud, Kondjoyan, Collignan, \& Sarter, 2013; Nagel, Bauermeister, Bratcher, Singh, \& McKee, 2013).The effectiveness of such treatments can depend on parameter such as, the chemical and concentration applied and the duration of treatment (Loretz et al., 2010). Potential negative effects on sensory properties of chicken meat after chemical treatments have been reported (Bilgili, Conner, Pinion, \& Tamblyn, 1998). The current study aimed to investigate the efficacy of combination treatments with a number of chemicals and ultrasound on bacterial decontamination of raw chicken.

While treatment type was a significant predictor of bacterial reduction in all three models constructed, comparisons between each chemical and its corresponding combination with US demonstrated significant differences for individual microbial groups and treatments. All combination treatments resulted in significant reductions in $C$. jejuni numbers compared to individual treatments; in contrast, no such differences were observed for TEC and only a single combination treatment lead to significant reductions in TVC. The susceptibility of microorganisms to US could be dependent on many factors such as size, shape and type of microorganism (Heinz, Alvarez, Angersbach, \& Knorr, 2001). which may account for the observations of the current study. For example larger cells have been reported to be naturally more susceptible to US due to increased area exposed. Gram-positive bacteria may be more resistant to the effects of US due to the protective action of the thicker cell wall. This may explain the inconsistent reductions observed in TVC, which is comprised of mixed bacterial populations, following combination treatments (Drakopoulou, Terzakis, Fountoulakis, Mantzavinos, \& Manios, 2009; Koolman et al., 2014). The variability between microorganisms in their reductions to these combinations may not only be related to their susceptibility to US, $C$. jejuni was also frequently reported to be more susceptible to SD than other Gram-negative bacteria (Hermans et al., 2010; Hilmarsson, Thormar, Thráinsson, Gunnarsson, \& Dadadóttir, 2006). The lipopolysaccharide layer in the cell membrane provides protection for Gram-negative bacteria against the antibacterial activity of fatty acids however, differences in the structure of this layer between species can lead to differences in susceptibility, with $C$. jejuni exhibiting the highest degree of susceptibility (Hinton, 2011). Due to its variable morphological characteristics $C$. jejuni is also known to have coccoid forms in aerobic conditions with weaker attachment ability than the spiral form on chicken skin (Jang et al., 2007). Therefore, it is possible that the effect of TSP was greater on weakly attached bacteria, may be because of the detergent effect of TSP on bacterial attachment (Cabedo, Sofos, \& Smith, 1996; Chen et al., 2012; Dinçer \& Baysal, 2004).

Recently there has been increased interest in the combination of US technology with heat (thermosonication) or pressure (manosonication) or both (thermomanosonication) (Alarcon-Rojo et al., 2015). Such combinations may enhance bacterial reductions while reducing both the duration and severity of thermal treatment, thus minimizing changes to organoleptic properties and may result in significant energy savings (Chemat, E-Huma, \& Khan, 2011). Results of our study agree with other researchers, that higher temperatures may increase the effectiveness of ultrasonication and chemical treatments to decrease $C$. jejuni counts and spoilage bacteria compared to ambient temperature (Alonso-Hernando, Guevara-Franco, Alonso-Calleja, \& Capita, 2013; Haughton et al., 2012). Increasing the temperature during the application of such treatments may lead to a weakened cell wall and leave the cell membrane less protected and more susceptible to the other treatments (Álvarez, Mañas, Sala, Condón, \& Man, 2003). Effective decontamination by ultrasound alone often requires prolonged treatment times (Haughton et al., 2012). Extended exposure to high intensity ultrasonication can result in increased temperatures and consequently may affect product quality and alter sensory and nutritional characteristics (Lado \& Yousef, 2002; Piyasena, Mohareb, \& McKellar, 2003). Therefore, combining mild heat and ultrasonication could effectively reduce the requirement for longer treatment times and associated damage to raw chicken products (Morild, Christiansen, Sørensen, Nonboe, \& Aabo, 2011).

Results of our study demonstrate that time was a significant predictor of reductions in $C$. jejuni and TEC. The effect of time on the reduction of spoilage bacteria was not consistent, likely due to the variability of these microorganisms and differences in their susceptibility to heat and the relatively short treatment times used in this study. Finally, additional work would be required to assess the effect of combining US with chemical treatments on sensory attributes in raw chicken.

\section{Conclusion}

Combinations of US and certain chemical treatments are promising decontamination technologies when applied with mild heat resulting in significant reductions of $C$. jejuni and spoilage bacteria on chicken skin. Our study also demonstrates the significant influence of temperature and time on microbial reductions when these combinations are applied.

\section{Acknowledgement}

The authors wish to acknowledge the financial support of the Iraqi Ministry of Higher Education and the University of Kufa.

\section{References}

Alarcon-Rojo, A. D., Janacua, H., Rodriguez, J. C., Paniwnyk, L., \& Mason, T. J. (2015). Power ultrasound in meat processing. Meat Science, 107, 86-93. http://dx.doi.org/ 10.1016/j.meatsci.2015.04.015.

Alexandre, H., Mathieu, B., \& Charpentier, C. (1996). Alteration in membrane fluidity and lipid composition, and modulation of $\mathrm{H}+-$ ATPase activity in Saccharomyces Cerevisiae caused by decanoic acid. Microbiology, 142(3), 469-475. http://dx.doi. org/10.1099/13500872-142-3-469.

Alonso-Hernando, A., Alonso-Calleja, C., \& Capita, R. (2013). Effectiveness of several chemical decontamination treatments against Gram-negative bacteria on poultry during storage under different simulated cold chain disruptions. Food Control, 34(2), 574-580. http://dx.doi.org/10.1016/j.foodcont.2013.05.020.

Alonso-Hernando, A., Guevara-Franco, J. A., Alonso-Calleja, C., \& Capita, R. (2013). Effect of the temperature of the dipping solution on the antimicrobial effectiveness of various chemical decontaminants against pathogenic and spoilage bacteria on poultry. Journal of Food Protection, 76(5), 833-842. http://dx.doi.org/10.4315/0362028X.JFP-12-396.

Álvarez, I., Mañas, P., Sala, F. J., Condón, S., \& Man, P. (2003). Inactivation of Salmonella enterica Serovar Enteritidis by ultrasonic waves under pressure at different water activities. Society, 69(1), 668-672. http://dx.doi.org/10.1128/AEM.69.1.668.

Awad, T. S., Moharram, H. A., Shaltout, O. E., Asker, D., \& Youssef, M. M. (2012). Applications of ultrasound in analysis, processing and quality control of food: A review. Food Research International, 48(2), 410-427. http://dx.doi.org/10.1016/j. foodres.2012.05.004.

Bermúdez-Aguirre, D., Mobbs, T., \& Barbosa-Cánovas, G. V. (2011). Ultrasound applications in food processing. In H. Feng, G. Barbosa-Canovas, \& J. Weiss (Eds.). Ultrasound technologies for food and bioprocessing (pp. 65-105). New York, NY Springer New York. http://dx.doi.org/10.1007/978-1-4419-7472-3 3.

Bilgili, S. F., Conner, D. E., Pinion, J. L., \& Tamblyn, K. C. (1998). Broiler skin color as affected by organic acids: Influence of concentration and method of application. Poultry Science, 77(5), 752-757. http://dx.doi.org/10.1093/ps/77.5.752.

Bolder, N. M. (1997). Decontamination of meat and poultry carcasses. Trends in Food 
Science and Technology, 8(7), 221-227. http://dx.doi.org/10.1016/S0924-2244(97) 01040-6.

Cabedo, L., Sofos, J. N., \& Smith, G. C. (1996). Removal of bacteria from beef tissue by spray washing after different times of exposure to fecal material. Journal of Food Protection, 59(12), 1284-1287.

Capita, R., Alonso-Calleja, C., Garcia-Fernandez, M. C., \& Moreno, B. (2002). Review: Trisodium phosphate (TSP) treatment for decontamination of poultry. Food Science and Technology International, 8(1), 11-24. http://dx.doi.org/10.1106/ 108201302023118.

Capita, R., Alonso-calleja, C., Sierra, M., Moreno, B., \& Garcõâa-ferna, M. C. (2000). Effect of trisodium phosphate solutions washing on the sensory.pdf. 55, 2-4.

Cárcel, J. A., García-Pérez, J. V., Benedito, J., \& Mulet, A. (2012). Food process in novation through new technologies: Use of ultrasound. Journal of Food Engineering 110(2), 200-207. http://dx.doi.org/10.1016/j.jfoodeng.2011.05.038.

Chaine, A., Arnaud, E., Kondjoyan, A., Collignan, A., \& Sarter, S. (2013). Effect of steam and lactic acid treatments on the survival of Salmonella Enteritidis and Campylobacter jejuni inoculated on chicken skin. International Journal of Food Microbiology, 162(3), 276-282. http://dx.doi.org/10.1016/j.ijfoodmicro.2013.01.012.

Chandrapala, J., Oliver, C., Kentish, S., \& Ashokkumar, M. (2012). Ultrasonics in food processing - Food quality assurance and food safety. Trends in Food Science \& Technology, 26(2), 88-98. http://dx.doi.org/10.1016/j.tifs.2012.01.010.

Chemat, F., E-Huma, Z., \& Khan, M. K. (2011). Applications of ultrasound in food technology: Processing, preservation and extraction. Ultrasonics Sonochemistry, 18(4), 813-835. http://dx.doi.org/10.1016/j.ultsonch.2010.11.023.

Chen, J. H., Ren, Y., Seow, J., Liu, T., Bang, W. S., \& Yuk, H. G. (2012). Intervention technologies for ensuring microbiological safety of meat: Current and future trends. Comprehensive Reviews in Food Science and Food Safety, 11(2), 119-132. http://dx.doi. org/10.1111/j.1541-4337.2011.00177.x.

Del Río, E., Panizo-Morán, M., Prieto, M., Alonso-Calleja, C., \& Capita, R. (2007). Effect of various chemical decontamination treatments on natural microflora and sensory characteristics of poultry. International Journal of Food Microbiology, 115(3), 268-280. http://dx.doi.org/10.1016/j.ijfoodmicro.2006.10.048.

Demirci, A., \& Ngadi, M. O. (2012). Microbial decontamination in the food industry: Novel methods and applications. Microbial decontamination in the food industry: Novel methods and applicationsElsevier Ltd.. Retrieved from http://www.scopus.com/ inward/record.url?eid = 2-s2.0-84902947236\&partnerID = tZOtx3y1.

Dibner, J. J., \& Buttin, P. (2002). Use of organic acids as a model to study the impact of gut microflora on nutrition and metabolism 1 DESCRIPTION OF PROBLEM gastrointestinal microbial populations- Ubiquitous and heterogeneous-Play a complex. Journal of Applied Poultry Research, 11, 453-463. http://dx.doi.org/10.1093/japr/11. 4.453.

Dinçer, a. H., \& Baysal, T. (2004). Decontamination techniques of pathogen bacteria in meat and poultry. Critical Reviews in Microbiology, 30(3), 197-204. http://dx.doi.org/ 10.1080/10408410490468803.

Drakopoulou, S., Terzakis, S., Fountoulakis, M. S., Mantzavinos, D., \& Manios, T. (2009). Ultrasound-induced inactivation of gram-negative and gram-positive bacteria in secondary treated municipal wastewater. Ultrasonics Sonochemistry, 16(5), 629-634. http://dx.doi.org/10.1016/j.ultsonch.2008.11.011.

European Food Safety Authority (2014). EFSA explains zoonotic diseases. Campylobacter, 1-2. http://dx.doi.org/10.2805/59450.

European Food Safety Authority (EFSA) (2013). The European Union summary report on trends and sources of zoonoses, zoonotic agents and food-borne outbreaks in 2011. EFSA Journal, 11(4), 3129. http://dx.doi.org/10.2903/j.efsa.2012.2597.

European Food Safety Authority (EFSA) (2015). Trends and sources of zoonoses, zoonotic agents and food-borne. 13(1)http://dx.doi.org/10.2903/j.efsa.2015.3991.

Food Safety Authority of Ireland (2011). Campylobacter species. Microbial Factsheet Series, $1,1-5$.

Food Safety Authority of Ireland (FSAI) (2002). Control of Campylobacter species in the food chain. Control.

Haughton, P. N., Lyng, J. G., Morgan, D. J., Cronin, D. A., Noci, F., Fanning, S., \& Whyte, P. (2012). An evaluation of the potential of high-intensity ultrasound for improving the microbial safety of poultry. Food and Bioprocess Technology, 5(3), 992-998. http://dx.doi.org/10.1007/s11947-010-0372-y.

Health Protection Surveillance Center (2016). Annual epidemiological report 2015, (1649-436). Retrieved from http://www.hpsc.ie/AboutHPSC/AnnualReports/File, 15956,en.pdf.

Heinz, V., Alvarez, I., Angersbach, A., \& Knorr, D. (2001). Preservation of liquid foods by high intensity pulsed electric fields - Basic concepts for process design. Trends in Food Science and Technology, 12(3-4), 103-111. http://dx.doi.org/10.1016/S09242244(01)00064-4.

Hermans, D., Martel, a., Van Deun, K., Verlinden, M., Van Immerseel, F., Garmyn, A., ... Pasmans, F. (2010). Intestinal mucus protects Campylobacter jejuni in the ceca of colonized broiler chickens against the bactericidal effects of medium-chain fatty acids. Poultry Science, 89(6), 1144-1155. http://dx.doi.org/10.3382/ps.2010-00717.
Hilmarsson, H., Thormar, H., Thráinsson, J. H., Gunnarsson, E., \& Dadadóttir, S. (2006). Effect of glycerol monocaprate (monocaprin) on broiler chickens: An attempt at reducing intestinal Campylobacter infection. Poultry Science, 85(4), 588-592. http://dx. doi.org/10.1093/ps/85.4.588

Hinton, A., Jr. (2011). Bactericidal activity of alkaline salts of fatty acids towards bacteria associated with poultry processing - Engormix. In XXII latin american poultry congress 2011 (p. \#156). Buenos aires, Argentina: Meeting proceedings. Retrieved from http://en.engormix.com/MA-poultry-industry/health/articles/bactericidal-activityalkaline-salts-t1747/165-p0.htm.

Jang, K.-I., Kim, M.-G., Ha, S.-D., Kim, K.-S., Lee, K.-H., Duck-Hwa Chung5, C.-H. K., \& Kim, K.-Y. (2007). Morphology and adhesion of Campylobacter jejuni to chicken skin under varying conditions. Journal of Microbiology and Biotechnology, 17(2), 202-206.

Koolman, L., Whyte, P., Meade, J., Lyng, J., \& Bolton, D. (2014). A combination of chemical and ultrasonication treatments to reduce Campylobacter jejuni on raw poultry. Food and Bioprocess Technology, 7(12), 3602-3607. http://dx.doi.org/10. 1007/s11947-014-1370-2.

Lado, B. H., \& Yousef, A. E. (2002). Alternative food-preservation technologies: Efficacy and mechanisms. Microbes and Infection, 4(4), 433-440. http://dx.doi.org/10.1016/ S1286-4579(02)01557-5.

Lindqvist, R., \& Lindblad, M. (2008). Quantitative risk assessment of thermophilic Campylobacter spp. and cross-contamination during handling of raw broiler chickens evaluating strategies at the producer level to reduce human campylobacteriosis in Sweden. International Journal of Food Microbiology, 121(1), 41-52. http://dx.doi.org/ 10.1016/j.ijfoodmicro.2007.10.008.

Loretz, M., Stephan, R., \& Zweifel, C. (2010). Antimicrobial activity of decontamination treatments for poultry carcasses: A literature survey. Food Control, 21(6), 791-804. http://dx.doi.org/10.1016/j.foodcont.2009.11.007.

Mani-López, E., García, H. S., \& López-Malo, A. (2012). Organic acids as antimicrobials to control Salmonella in meat and poultry products. Food Research International, 45(2), 713-721. http://dx.doi.org/10.1016/j.foodres.2011.04.043.

Morild, R. K., Christiansen, P., Sørensen, A. H., Nonboe, U., \& Aabo, S. (2011). Inactivation of pathogens on pork by steam-ultrasound treatment. Journal of Food Protection, 74(5), 769-775. http://dx.doi.org/10.4315/0362-028X.JFP-10-338.

Nagel, G. M., Bauermeister, L. J., Bratcher, C. L., Singh, M., \& McKee, S. R. (2013). Salmonella and Campylobacter reduction and quality characteristics of poultry carcasses treated with various antimicrobials in a post-chill immersion tank. International Journal of Food Microbiology, 165(3), 281-286. http://dx.doi.org/10.1016/j. ijfoodmicro.2013.05.016.

Nauta, M., Hill, A., Rosenquist, H., Brynestad, S., Fetsch, A., van der Logt, P., ... Havelaar, A. (2009). A comparison of risk assessments on Campylobacter in broiler meat. International Journal of Food Microbiology, 129(2), 107-123. http://dx.doi.org/10. 1016/j.ijfoodmicro.2008.12.001.

Patriarchi, A., Maunsell, B., O'Mahony, E., Fox, Á., Fanning, S., Buckley, J., \& Bolton, D. J. (2009). Prevalence of Campylobacter spp. in a subset of intensive poultry flocks in Ireland. Letters in Applied Microbiology, 49(3), 305-310. http://dx.doi.org/10.1111/j. 1472-765X.2009.02658.x.

Piyasena, P., Mohareb, E., \& McKellar, R. C. (2003). Inactivation of microbes using ultrasound: A review. International Journal of Food Microbiology, 87(3), 207-216. http://dx.doi.org/10.1016/S0168-1605(03)00075-8.

Rosenquist, H., Boysen, L., Galliano, C., Nordentoft, S., Ethelberg, S., \& Borck, B. (2009) Danish strategies to control Campylobacter in broilers and broiler meat: Facts and effects. Epidemiology and Infection, 137(12), 1742-1750. http://dx.doi.org/10.1017/ S0950268809002684.

Smith, S., Meade, J., McGill, K., Gibbons, J., Bolton, D., \& Whyte, P. (2015). Restoring the selectivity of modified charcoal cefoperazone deoxycholate agar for the isolation of Campylobacter species using tazobactam, a $\beta$-lactamase inhibitor. International Journal of Food Microbiology, 210, 131-135. http://dx.doi.org/10.1016/j.ijfoodmicro.2015. 06.014.

Smith, S., Messam, L. L. M., Meade, J., Officer, T., Gibbons, J., Mcgill, K., \& Bolton, D. (2016). Differing levels of hygiene and economic performance. Infection Ecology and Epidemiology, 1(2), 1-8.

The European Commission (2013). Regulation (EC) N 101/2013 of the European Parliament and of the council of 4 February 2013 concerning the use of lactic acid to reduce microbiological surface contamination on bovine carcasses. Official Journal of the European Union, 9(7), 2011-2013.

Torley, P. J., \& Bhandari, B. R. (2004). Ultrasound in food processing and preservation. Food science and technology. 167. Food science and technology (pp. 713-). New York: Marcel Dekker.

USDA-FSIS (1996). Pathogen reduction; hazard analysis and critical control point (HACCP) systems. Federal Register, 61.

Whyte, P., McGill, K., Cowley, D., Madden, R. H., Moran, L., Scates, P., ... Cormican, M. (2004). Occurrence of Campylobacter in retail foods in Ireland. International Journal of Food Microbiology, 95(2), 111-118. http://dx.doi.org/10.1016/j.ijfoodmicro.2003. 10.018 . 